\title{
Polychaetes of the North-Central Santa Catarina state, Brazil
}

\author{
Tito Cesar Marques de Almeida ${ }^{1}$, Jorge Matheus Vivan ${ }^{1 *}$, Bruno Henrique Pesserl ${ }^{1}$ and Paulo da \\ Cunha Lana ${ }^{2}$ \\ 1 Universidade do Vale do Itajaí, CTTMar - Centro de Ciências Tecnológicas da Terra e do Mar, Laboratory of Aquatic Communities Ecology. Rua \\ Uruguai, 458, Centro Bloco 20 Sala 144, Caixa Postal 360. CEP 88302-202. Itajaí, SC, Brasil. \\ 2 Universidade Federal do Paraná, CEM - Centro de Estudos do Mar, Laboratory of benthos. Avenida Beira Mar s/n, Caixa Postal 50002. CEP 83255- \\ 000. Pontal do Paraná, PR, Brasil. \\ * Corresponding author. E-mail: jmatheusvivan@gmail.com
}

ABSTRACT: A preliminary checklist of polychaete species from the inner shelf of Santa Catarina state (S Brazil) is presented, based on material collected between $26^{\circ} 18^{\prime} \mathrm{S}-27^{\circ} 18^{\prime} \mathrm{S}$, in depths ranging from 5 to $15 \mathrm{~m}$. The checklist comprises 46 species belonging to 18 families. Sigambra pettiboneae (Hartman-Schröeder, 1979) is newly reported for the Brazilian coast. Mediomastus californiensis Hartman, 1944, Ninoe brasiliensis Kinberg, 1865, Neanthes bruaca Lana and Sovierzoski, 1987 and Paraprionospio pinnata (Ehlers, 1901) occurred in all samples. The distribution range of 22 other species was extended to the Santa Catarina coast.

\section{INTRODUCTION}

Polychaetes are among the most abundant groups in benthic samples, and may correspond to more than $2 / 3$ of benthic associations (Rouse and Pleijel 2006), exhibiting a diversity of body morphologies and feeding strategies (Glasby 2005; Rouse and Pleijel 2001).

In southern Brazil there are relevant taxonomic works at Paraná (Lana et al. 2006) and Rio Grande do Sul states (Orensanz and Gianuca 1974). However, no taxonomic surveys of polychaetes were carried out along the coast of the state of Santa Catarina. The only available records were provided in ecological works in coastal (Pagliosa 2006; Vivan et al. 2009) and shelf break areas (Rullier and Amoureux 1979; Rohr and Almeida 2006).

This first taxonomic list of Santa Catarina polychaetes provides a preliminary baseline for future taxonomic and ecological research. Species and families reported on this checklist are the result of surveys along the inner continental shelf, from São Francisco do Sul (2618' S) to Tijucas $\left(27^{\circ} 18^{\prime} \mathrm{S}\right)$, between 2001 to 2008 . Only organisms identified at specific level are listed.

\section{MATERIALS AND MeThodS}

Study site

Eleven sublittoral stations were sampled in depths ranging between 2 to $12 \mathrm{~m}$, along a latitudinal gradient of ca. $100 \mathrm{~km}$, from São Francisco do Sul (26¹8' S) to Tijucas cities or stations $\left(27^{\circ} 18^{\prime} \mathrm{S}\right)$ (Figure 1).

Each station is represented by a letter: A- São Francisco do Sul, B- Gravatá, C- North Navegantes, DSouth Navegantes, E- Atalaia beach, F- Brava beach, GNorth Balneário Camboriú, H- South Balneário Camboriú, I- Laranjeiras beach, J- Porto Belo, K- Tijucas (Figure 1). The stations represent sites or regions with distinct wave exposure degree. Station A, located on São Francisco do Sul was an exposed site, composed of fine and very fine sand, moderately selected. The region between Gravatá (station B) and Laranjeiras (station I) exhibited poorly selected silt and clay, while Porto Belo (station J) presented well selected coarse sediments (Almeida et al. 2004). Tijucas bay (station $\mathrm{K}$ ) was composed by muddy sediments.

\section{Sampling}

Biological samples were obtained with a $0.025 \mathrm{~m}^{2}$ and $0.042 \mathrm{~m}^{2}$ Van-Veen grab and a $0.018 \mathrm{~m}^{2}$ PVC corer. A total of 777 samples were collected from 2001 to 2008.

At least 30 samples from each station were analyzed. Samples were fixed in $4 \%$ formaldehyde and washed in

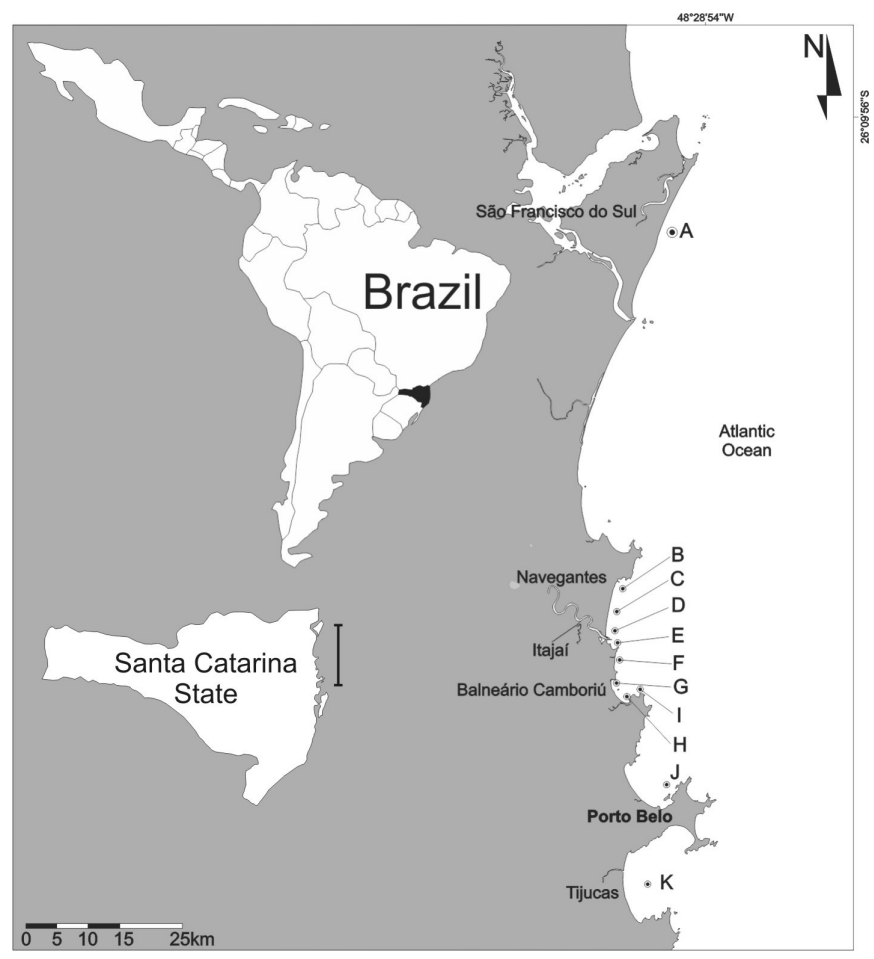

Figure 1. Map of Santa Catarina north-central coast and the sampling stations. A- São Francisco do Sul, B- Gravatá, C- North Navegantes, DSouth Navegantes, E- Atalaia beach, F- Brava beach, G- North Balneário Camboriú, H- South Balneário Camboriú, I- Laranjeiras beach, J- Porto Belo, K- Tijucas. The line in front of Santa Catarina coast indicates the study area. 
$0.5 \mathrm{~mm}$ mesh size; retained polychaetes were counted and identified from specific literature.

Voucher specimens were deposited at the Instituto de Biologia da Universidade Federal do Rio de Janeiro (IBUFRJ), Rio de Janeiro, RJ. Deposit numbers are provided for each species.

\section{RESULTS AND DISCUSSION}

A total of 9,739 polychaetes were collected, distributed in 127 morphotypes reported to 33 families. Forty-six species, distributed in 18 families (Table 1), were formally identified. Organisms belonging to the families Oweniidae,
Cirratulidae, Syllidae, Flabelligeridae, Cossuridae Hesionidae, Maldanidae, Pectinariidae, Pholoididae, Phyllodocidae, Sabellaridae, Scalibregmatidae, Terebellidae and Trichobranchidae were not identified to species level.

The species Mediomastus californiensis Hartman, 1944, Ninoe brasiliensis Kinberg, 1865, Magelona posterelongata Bolivar and Lana, 1986, Neanthes bruaca Lana and Sovierzoski, 1987 and Paraprionospio pinnata (Ehlers, 1901) occurred in all sampled sites.

Hemipodia simplex (Grube, 1857), Gymnonereis crosslandi (Monro, 1933), Nephtys squamosa (Ehlers,

TABLE 1. List of polychaetes species and their regional distribution along the Santa Catarina north-central coast. Letters correspond to the species occurrence at sampling stations as indicated in Figure 1.

\begin{tabular}{|c|c|c|c|}
\hline DEPOSIT NUMBER & FAMILY & SPECIES & OCCURRENCE \\
\hline IBUFRJ-1110 & Ampharetidae & Linopherus ambigua (Monro, 1933) & $\mathrm{J}$ \\
\hline IBUFRJ-1111 & & Isolda pulchella Müller, 1858 & $\mathrm{JK}$ \\
\hline IBUFRJ-1112 & Capitellidae & Capitella cf. capitata (Fabricius, 1740) & DJ \\
\hline IBUFRJ-1113 & & Heteromastus similis Soutthern, 1921 & $\mathrm{D}$ \\
\hline IBUFRJ-1114 & & Mediomastus californiensis Hartman, 1944 & ABCDEFGHIJK \\
\hline IBUFRJ-1115 & & Notomastus lobatus (Hartman, 1947) & ADJK \\
\hline IBUFRJ-1116 & Dorvilleidae & Schistomeringos rudolphi (delle Chiaje, 1828) & $\mathrm{K}$ \\
\hline IBUFRJ-1117 & Glyceridae & Hemipodia simplex (Grube, 1857) & A \\
\hline IBUFRJ-1118 & Goniadidae & Goniada maculata Oersted, 1843 & BCDEFGHIJK \\
\hline IBUFRJ-1119 & & Goniada littorea Hartman, 1950 & $\mathrm{AD}$ \\
\hline IBUFRJ-1120 & Lumbrineridae & Lumbricalus januarii (Grube, 1878) & $\mathrm{J}$ \\
\hline IBUFRJ-1121 & & Lumbrinereis atlantica (Kinberg, 1865) & $\mathrm{AD}$ \\
\hline IBUFRJ-1122 & & Ninoe brasiliensis Kinberg, 1865 & ABCDEFGHIJK \\
\hline IBUFRJ-1123 & Magelonidae & Magelona crenulata Bolivar and Lana, 1986 & $\mathrm{~K}$ \\
\hline IBUFRJ-1124 & & Magelona papillicornis Müller, 1858 & ABCDEFGHIK \\
\hline IBUFRJ-1125 & & Magelona posterolongata Bolívar and Lana, 1986 & ABCDEFGHIJK \\
\hline IBUFRJ-1126 & & Magelona variolamelata Bolivar and Lana, 1986 & ABDEFGHIJK \\
\hline IBUFRJ-1127 & & Magelona riojai Jones, 1963 & $\mathrm{D}$ \\
\hline IBUFRJ-1128 & Nereididae & Gymnonereis crosslandi (Monro, 1933) & A \\
\hline IBUFRJ-1129 & & Neanthes bruaca Lana and Sovierzoski, 1987 & ABCDEFGHIJK \\
\hline IBUFRJ-1130 & & Alitta succinea (Frey and Leuckart, 1847) & HI \\
\hline IBUFRJ-1131 & Nephtyidae & Aglaophamus juvenalis Kinberg, 1866 & $\mathrm{~J}$ \\
\hline IBUFRJ-1132 & & Inermonephtys brasiliensis Martin, Gil and Lana, 2009 & $\mathrm{AD}$ \\
\hline IBUFRJ-1133 & & Nephtys squamosa (Ehlers, 1887) & A \\
\hline IBUFRJ-1134 & Onuphidae & Kinbergonuphis difficilis (Fauchald, 1982) & BCDEFGHI \\
\hline IBUFRJ-1135 & & Kinbergonuphis nonatoi Lana, 1991 & A \\
\hline IBUFRJ-1136 & & Kinbergonuphis orensanzi (Fauchald, 1982) & $\mathrm{K}$ \\
\hline IBUFRJ-1137 & & Onuphis eremita oculata Hartman, 1951 & A \\
\hline IBUFRJ-1138 & Opheliidae & Armandia hossfeldi (Hartman-Schroeder, 1956) & AFGHJ \\
\hline IBUFRJ-1139 & Orbiniidae & Phylo felix Kinberg, 1866 & $\mathrm{~J}$ \\
\hline IBUFRJ-1140 & Paraonidae & Cirrophorus branchiatus (Ehlers, 1908) & BEFGHIJK \\
\hline IBUFRJ-1141 & Pilargidae & Ancistrosyllis jonesi Pettibone, 1966 & $\mathrm{AD}$ \\
\hline IBUFRJ-1142 & & Loandalia ocularis (Emerson and Fauchald, 1971) & DJ \\
\hline IBUFRJ-1143 & & Hermundura tricuspis (Müller, 1858) & $\mathrm{ADJK}$ \\
\hline IBUFRJ-1144 & & Sigambra pettiboneae (Hartman-Schroder, 1979) & BCDFGHI \\
\hline IBUFRJ-1146 & Poecilochaetidae & Poecilochaetus australis Nonato, 1963 & ADHK \\
\hline IBUFRJ-1147 & & Poecilochaetus polycirratus Santos and Mackie, 2008 & $\mathrm{~J}$ \\
\hline IBUFRJ-1148 & Polynoidae & Eunoe serrata Amaral and Nonato, 1982 & A \\
\hline IBUFRJ-1149 & Sigalionidae & Sthenelais limicola (Ehlers, 1864) & BFHIJ \\
\hline IBUFRJ-1150 & Spionidae & Dispio remanei Friedrich, 1956 & BCEFGHI \\
\hline IBUFRJ-1151 & & Laonice branchiata Nonato, Bolivar and Lana, 1986 & $\mathrm{~J}$ \\
\hline IBUFRJ-1152 & & Laonice cirrata (Sars, 1850) & JK \\
\hline IBUFRJ-1153 & & Paraprionospio pinnata (Ehlers, 1901) & ABCDEFGHIJK \\
\hline IBUFRJ-1154 & & Prionospio dayi (Foster, 1969) & ADHIK \\
\hline IBUFRJ-1155 & & Prionospio steenstrupi (Malmgren,1867) & CK \\
\hline IBUFRJ-1156 & & Spiophanes bombyx (Claparede, 1870) & $\mathrm{J}$ \\
\hline
\end{tabular}


1887), Kinbergonuphis nonatoi Lana,1991, Onuphis eremita oculata Hartman, 1951, and Eunoe serrata Amaral and Nonato, 1982 occurred exclusively in the northern sector (São Francisco do Sul) (Station A).

Linopherus ambigua (Monro, 1933), Isolda pulchella Muller, 1858, Lumbricalus januarii (Grube, 1878), Magelona crenulata Bolivar and Lana, 1986, Aglaophamus juvenalis Kinberg, 1866, Kinbergonuphis orensanzi (Fauchald, 1982), Phylo felix Kinberg, 1866, Poecilochaetus polycirratus Santos and Mackie, 2008, Laonice branchiata Nonato, Bolívar and Lana, 1986, Laonice cirrata (Sars, 1850), and Spiophanes bombyx (Claparède, 1870) occurred exclusively in southern, in Porto Belo (Station J) and/or Tijucas (Station K) (Table 1).

The central to north coast of Santa Catarina state, is a region considered as part of the Warm Temperate Southwestern Atlantic Province (Spalding et al., 2007). The 46 species identified were the more conspicuous in abundance and frequency, on the other hand 127 morphotypes were recognize representing the biodiversity of the subtidal zone between 5 and 15 meters depth. Twenty-two species, previously known from Rio Grande do Sul to São Paulo states were first recorded in Santa Catarina covering the gap for the south Brazilian coast.

The bottom of the area sampled is formed by sand and mud and has a different geographical orientation that determine a different level of exposure by incident waves that influence the granulometric composition (Klein and Menezes 2001). According to the different bottom type three groups of species were identified. The first was integrated by five species (M. californiensis, $N$. brasiliensis, N. bruaca, M. posterolongata and P. pinnata) and corresponds to species that occurred in all stations. Another group formed by seven species ( $H$. simplex, $L$. brasiliensis, G. crosslandi, N. squamosa, K. nonatoi, Onuphis eremita oculata, and E. serrata) represents the sandy bottom found on the extreme north station (A). The third and last group represented the muddy bottom in the stations from the bays ( $\mathrm{J}$ and $\mathrm{K}$ ) and were composed by 12 species (L. ambigua, I. pulchella, S. cf. rudolphi, $L$. januarii, $M$. crenulata, A. juvenalis, $K$. orensanzi, $P$. felix, $P$. polycirratus, L. branquiata, L. branquiata, and S. bombyx).
ACKNOWLEDGMENTS: The authors would like to thanks to Porto de Itajaí and FNMA (Fundação Nacional do Meio Ambiente) for financial support in surveys and UNIVALI (University of the Itajaí Valley) for logistical support.

\section{Literature Cited}

Glasby, C.J. 2005. Polychaete Distribution Patterns Revised: an Historical Explanation. Marine Ecology 26: 235-245.

Gray, J.S. and Elliott, M. 2009. Ecology of Marine Sediments. Oxford: University Press. Second Edition. 225 p.

Klein, A.H.F. and Menezes, J.T. 2001. Beach Morphodynamics and Profile Sequence for a Headland Bay Coast. Journal of Coastal Research 17(4): 812-835.

Lana, P.C., C.S.G. Santos, A.R. Garrafoni, V.M. Oliveira and V. Radashevsky. 2006. Checklist of polychaete species from Paraná State (Southern Brazil). Check List 2(3): 30-63.

Orensanz, J.M. and N.M. Gianuca. 1974. Contribuição ao conhecimento dos anelídeos poliquetas do Rio Grande do sul, Brasil. I. Lista sistemática preliminar e descrição de três novas espécies. Comunicações do Museu de Ciências da PUCRGS 4: 1-37.

Pagliosa, P.R. 2006. Distribuição da macrofauna bêntica do entremarés ao sublitoral em uma praia estuarina da Baía da Babitonga, Sul do Brasil. Revista Biotemas 19(1): 25-33.

Rohr, T.E. and T.C.M. Almeida. 2006. Anelídeos poliquetas da plataforma continental externa ao largo do estado de Santa Catarina - Brasil: situação de verão e inverno. Brazilian Journal of Aquatic Science and Technology 10(1): 41-50.

Roulier, F. and Amoureux, L. 1979. Annélides polychètes. Campagne de la Calypso au large des côtes atlantiques de l'Amérique du Sud (19611962). Annales de l'linstitut Océanographique, Paris, 44: 10-206.

Rouse, G.W. and F. Pleijel. 2001. Polychaeta. Oxford: University Press. 354 p.

Rouse, G.W. and F. Pleijel. 2006. Annelid Phylogeny and Systematics; p. 788-789. In G.W. Rouse and F. Pleijel (ed.). Reproductive Biology and Phylogeny of Annelida. Enfiel: Science Publishers.

Spalding, M.D., Fox, H.E., Allen, G.R., Davidson, N., Ferdaña, Z.A., Finlayson, M., Halpern, B.S., Jorge, M.A., Lombana, A., Lourie, S.A., Martin, K.D., McManus, E., Molnar, J., Recchia, C.A. and Robertson, J. 2007. Marine Ecoregions of the World: A Bioregionalization of Coastal and Shelf Areas. Bioscience 57(7): 573-583.

Vivan, J.M., Di Domenico, M. and T.C.M. Almeida. 2009. Effects of dredged material disposal on benthic macrofauna near Itajaí harbour (Santa Catarina, South Brazil). Ecological Engineering 35: 1435-1443.

Wijsman, J.W.M., Herman, P.M.J. and Gomoiu, M.T. 1999. Spatial Distribution in Sediment Characteristics and Benthic Activity on the Northwestern Black Sea Shelf. Marine Ecology Progress Series 181: 25-39.

RECEIVED: May 2011

ACCEPTED: February 2012

Published online: May 2012

EDITORIAL RESPONSIBILITY: Rodrigo Johnsson 